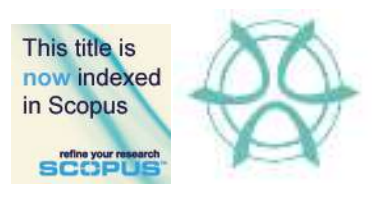

PLANNING MALAYSIA:

Journal of the Malaysian Institute of Planners

VOLUME 18 ISSUE 4 (2020), Page 12 - 32

\title{
SETTING THE CRITERIA FOR URBAN TREE VANDALISM ASSESSMENT
}

\author{
Helmi Hamzah$^{1}$, Noriah Othman ${ }^{2}$, Nur Huzeima Mohd Hussain ${ }^{3}$ \\ ${ }^{1,2,3}$ Faculty of Architecture, Planning and Surveying \\ UNIVERSITI TEKNOLOGI MARA MALAYSIA
}

\begin{abstract}
An urban tree monitoring programme is a management procedure that determines the performance status of trees by conducting an inventory of the number of trees, their condition, their structure, and other quantitative or qualitative characteristics. The ability to successfully carry out a monitoring programme is highly dependent on precise data. At the same time, comprehensive and strategic urban tree policies require accurate baseline and trending data. Accordingly, there is a need for an improved assessment technique for tree monitoring. Due to the increasing number of tree vandalism incidents in urban areas, the immediate objective of this research was to determine the criteria for a precise tree vandalism assessment technique. A modified Delphi method was adopted to obtain the most reliable consensus among tree care experts through a series of questionnaires. Prior to conducting the Delphi survey, the initial tree vandalism criteria were identified through a preliminary survey conducted by means of the photoelicitation technique. Experts provided the input for generating the criteria, and at the end of the second round of the Delphi survey, the experts reached a consensus on a set of criteria, which included 10 criteria related to aspects of specific motives and actions, 11 criteria related to aspects of ideologies and practices, and 11 other criteria related to the aspect of victim of circumstances. The selected criteria can be applied in a monitoring programme to assess the incidence of tree vandalism.
\end{abstract}

Keywords: Delphi Method, Tree Management, Tree Monitoring, Tree Vandalism

${ }^{1}$ Lecturer at Universiti Teknologi MARA. Email: helmi.treev@gmail.com 
PLANNING MALAYSIA

Journal of the Malaysia Institute of Planners (2020)

\section{INTRODUCTION}

An urban tree monitoring programme is believed to play an important role in guiding policymakers and tree managers in making decisions to improve planting programmes. A standard monitoring procedure should cover aspects of the structures, functions and health of urban trees. It has been suggested that urban tree monitoring efforts are more about the performance of urban trees in response to those policies or management strategies. In this case, site attributes (land use and type of site) and tree attributes (GPS coordinates, species, diameter at breast height, mortality status, and tree condition) are measured to counter-check against the aims and goals of the management (UTGL, 2015).

However, these approaches are becoming increasingly unreliable, where the social attributes are underestimated, especially in the context of tree vandalism. Researches tend to focus on physical attributes rather than social attributes. Despite these observations, the assessment technique for tree vandalism remains unclear. Hence, additional studies on the assessment of tree vandalism for tree monitoring programs are needed.

The objective of this research was to determine the criteria that can be used to assess the incidence of tree vandalism in urban areas. This research focused on a strategy to guide decision-makers and tree managers in making the right decisions with regard to the issue of tree vandalism. This approach will provide an effective monitoring program for urban tree management. The remainder of this paper is divided into three sections. After the introduction and the literature review, the second section clarifies the methodology, while the third section presents the results of the study. Finally, the fourth section provides the conclusions and suggestions for future research.

\section{LITERATURE REVIEW}

Trees and vandalism are old issues that deserve new thought. Vandalism causes harmful consequences that affect the performance of trees in terms of their contribution to ecosystem services. Some scholars have explained that tree vandalism may reduce the number of safe and comfortable environmental spaces (Donovan \& Prestemon, 2012; Hami, Suhardi, Manohar, \& Malekizadeh, 2014; Hasan, Othman, \& Ismail, 2018; Mohd Yunos \& Md Saring, 2012), lower tree appraisal values (Grande-Ortiz, Ayuga-Téllez, \& Contato-Carol, 2012) and increase environmental degradation (Roy, Byrne, \& Pickering, 2012). Vandalism is synonymous with mechanical injuries that become the starting point for tree damage, thereby leading to tree failure (Moore, 2013). These phenomena are known as tree disservices, and they result in unexpected economic costs, physical damage to the infrastructure, and create fears or inconveniences due to poor health conditions (Lyytimäki, 2017). Hence, it is important to address the incidence of tree vandalism in order to mitigate tree disservices and sustain urban trees. Therefore, in this study, tree vandalism is defined as an act that may cause 
Helmi Hamzah, Noriah Othman, Nur Huzeima Mohd Hussain

Setting the Criteria for Urban Tree Vandalism Assessment

damage to trees, and thus, have deleterious effects on the economy, society and environment. The economic, social and environmental deterioration will definitely have a negative impact on the well-being of humans, who depend on the benefits provided by trees in urban areas.

There is a lack of urban tree monitoring guidelines or models that can guide decision-makers and urban tree managers specifically with regard to the subject of the incidence of tree vandalism. Thus, although urban trees are being managed with good strategies and implementation efforts, the issue of urban tree vandalism remains unresolved. The incidence of tree vandalism is increasing annually in most cities in the world (Hamzah, Othman, Mohd Hussain, \& Simis, 2018; Mullaney, Lucke, \& Trueman, 2015; Sieghardt et al., 2005). It occurs at all stages of urban tree management, either at the planning, implementation or maintenance stage. Implementing an urban tree monitoring program is recognized as a practical approach for interpreting the incidence of urban tree vandalism as it can explain in detail the factors of failure. However, existing urban tree monitoring programs do not look specifically into urban tree vandalism issues, especially in terms of the social factors, at all stages of tree management. Subsequently, the status of the incidence of tree vandalism, which may explain the significant criteria and activities, is unknown. As such, there is a lack of proper monitoring mechanisms in urban tree management to improve their strategies and implementation toward tree vandalism issues.

The references for an urban tree monitoring manual were mostly developed by the Urban Tree Growth and Longevity (UTGL) Working Group. The manual, known as the "Urban Tree Monitoring Protocols: Field Guide", was published by the UTGL (2015). Its aim is to provide a standardized long-term data collection method for urban tree monitoring programs. It involves field collection procedures for five datasets of variables. The datasets include a: (1) Minimum Dataset - field crew information, location, site type, tree species, diameter at breast height, mortality status, and fine twig dieback; (2) Site Dataset - the characteristics of the site surrounding the trees, including the planting site, soils, and built environment; (3) Tree Dataset - tree growth, and health issues, including height, crown spread, maintenance tasks, and presence of pests and diseases; (4) Management Dataset - tree care practices by local organizations, including information institutions that plant and care for trees; and (5) Community Dataset - socioeconomic information of the community surrounding the trees, including income, housing value, and population density. Based on the datasets outlined in this manual, information relating to social attributes is lacking, and it is difficult to relate the data with the incidence of tree vandalism. To fill this gap, this research was undertaken to investigate the significant criteria that influence the incidence of tree vandalism. The criteria that were determined were then verified to assess the incidence of tree vandalism in urban areas. The results generated through this tree vandalism assessment are expected to provide 
evidence to decision-makers and tree managers on the necessary collective efforts required to solve problems of tree vandalism in their management.

Researchers have conducted some studies on urban tree conditions that affect public preferences (Abd Kadir \& Othman, 2012; Hamzah, Othman, \& Mohd Hussain, 2017). These studies examined tree conditions that could influence the incidence of tree vandalism. It is common sense that people would reject trees that cause them problems. A study by Hamzah et al. (2017) found that the Kajang local authority received 935 public applications for the removal of trees in 2016. It can be concluded that this was due to the fear of the public of the risk to their safety that would be inflicted by dangerous tree conditions such as overgrown trees. Furthermore, a preliminary study in old Klang town carried out by Abd Kadir \& Othman (2012) found that there are issues regarding the condition of urban trees that contribute to the inconvenience experienced by Klang citizens. Abd Kadir \& Othman (2012) revealed that the issues had to do with overgrown trees, the conflict of urban trees versus overhead utility lines, minimum shading capability (poor tree canopy coverage), and aggressive urban tree roots that damaged sidewalks or paved areas. Those were among the tree conditions that were deemed a public inconvenience.

A growing number of studies have investigated the human misconduct behind the vandalisation of trees across urban areas. Previous studies noted that human misconduct led to the widespread vandalisation of urban trees across the city centre of Oakland (California), eleven cities in the north of England, Eastern Cape (South Africa), and Mexico City (Gilbertson \& Bradshaw, 1985; Hernández Zaragoza et al., 2015; Nowak, McBride, \& Beatty, 1990; Richardson \& Shackleton, 2014). The authors almost exclusively cited differences in attitude toward urban trees as a major factor in the tree vandalism incidents, with a pessimistic, rather than an optimistic, attitude contributing to the higher incidence of tree vandalism. The issue of personal attitude and its relationship with the incidence of tree vandalism was briefly addressed by Long \& Burke (2015) and Richardson \& Shackleton (2014), where people who are bored, have a passion for delinquency, negative behaviour, and lack of appreciation for trees contribute to a high incidence of tree vandalism.

The term "urban stresses" means that urban trees are constrained in their growth and performance due to threats from malicious, accidental and other anthropogenic activities (Osakabe, Kawaoka, Nishikubo, \& Osakabe, 2012; Vogt, Watkins, Mincey, Patterson, \& Fischer, 2015). Urban stresses give rise to poor tree conditions and disservices that impact all urban tree populations (Delshammar, Östberg, \& Öxell, 2015; Lyytimäki, 2017). The studies detailed above outline the factors that affect "human misconduct" (e.g. poor workmanship approaches and ignorance of urban trees) in a dynamic urban environment, and its detrimental impact on urban tree populations. The nature of the dynamic 
Helmi Hamzah, Noriah Othman, Nur Huzeima Mohd Hussain

Setting the Criteria for Urban Tree Vandalism Assessment

characteristics across an urban area would mean that urban trees are exposed to urban stresses, leading to deliberate or accidental incidents of vandalism.

Thus, the factors that influence the incidence of urban tree vandalism can be categorized into three criteria, namely, tree conditions, humans and the environment. The criteria of tree conditions refer to the characteristics of urban trees, while the human criteria refer to human misconduct, as well as safety and convenience. Finally, the environmental criteria refer to anthropogenic factors.

\section{MATERIALS AND METHODS \\ Research Design}

A two-round modified Delphi technique was used to solicit the independent opinions of experts in constructing a set of criteria for the assessment of tree vandalism. In this modified Delphi technique, the qualitative round (first round) was replaced by a preliminary survey (Stewart et al., 2017). The preliminary survey employed a photo-elicitation technique comprised of 35 damaged tree situations that were interpreted by the expert respondents as vandalism incidents. The initial criteria, which were generated from a preliminary survey, were then used to guide the development of statements for the Delphi questionnaire rounds. The final set of criteria developed at round two of the Delphi survey was then evaluated in terms of their ranking and importance, which were consistent with the budget allocation process (BAP) (Greco, Ishizaka, Tasiou, \& Torrisi, 2019; Nardo, Saisana, Saltelli, \& Tarantola, 2005).

\section{Data Analysis}

Qualitative data from a preliminary survey were extracted through a coding analysis using the NVivo 11 program. All the interpretations of the experts were transcribed and imported into the program. Then, the main ideas in each answer were coded (Mayring, 2000). As many categories as needed were created to synthesize the information provided in the survey that had been mapped with the identified criteria for tree vandalism incidents. Next, similar categories were merged to find patterns.

A descriptive data analysis for the first and second rounds of the Delphi survey was undertaken using the Statistical Package for the Social Sciences (SPSS) version 25. The group mean was used to determine the consensus among the experts (Alvarez Etxeberria, Garayar, \& Calvo Sánchez, 2015; Henning \& Jordaan, 2016; Salazar-Elena, Sánchez, \& Otamendi, 2016). The impact value of each criterion on the incidence of tree vandalism was calculated from the weightage ranking in round two of the Delphi survey.

\section{Selection of Expert Respondents}

The expert respondents involved in this study (both in the preliminary and Delphi survey) were Malaysian tree care experts who were qualified as Certified 
Arborists by the International Society of Arboriculture (I.S.A.). The preliminary survey questionnaires were handed to 92 Malaysian certified arborists in the form of a Google survey through email. Consistent with Sekaran \& Bougie (2016), this survey adopted the rule of thumb for most researches, where the sample size should be larger than 30 samples and the minimum size of a sample should be $30 \%$ of the population.

A total of 60 potential experts, who had been identified for the Delphi survey, were informed and invited to participate in the research. However, only 47 respondents agreed to participate. A total of 30 responses were received for round one of the surveys. However, after the second round, 12 experts dropped out due to time constraints, leaving a remainder of 18 experts. This number was acceptable since it was consistent with the Delphi sample size of between 10 to 60 (Hasson, Keeney, \& McKenna, 2000; Bogner, Littig, \& Menz, 2009; Jeste et al., 2010). Local experts from various employment sectors related to urban tree management were engaged to elicit their ideas and responses. The group consisted of six main players; the researcher, academia, local authority, consultant, contractor, and federal government sectors. Specifically, all the potential respondents were selected based on at least one of the following criteria: (1) established academics who have either published their work in international journals or have lectured in the field of urban tree management; (2) established practitioners who have extensive experience in urban tree management; (3) officers from federal and local governments who have been involved in decision making or in managing urban tree planting programs; and (4) public from nongovernmental organizations who have been involved in urban tree planting programs.

\section{Administration of the Delphi Survey}

In the Delphi procedure, several measures were taken to ensure the validity of the course of action. A formal letter of invitation was sent out via email to each of the 60 potential respondents identified earlier in the sample selection process. The letter of invitation included an explanation on the purpose of the research, a request for participation as an expert, and a feedback notification as to whether the potential respondent agreed or disagreed with this request. Within two weeks after the invitation letter was sent through email, a total of 47 experts gave their consent to participate. The questionnaire for round one of the survey was sent to the 47 experts who had agreed to participate. A total of 30 responses were received for this round of the survey. The questionnaire for the final (second) round of the survey was sent to all 30 experts who had previously participated in round one of the Delphi survey. In return, a total of 18 completed responses were received from these experts.

A Delphi survey approach was used for the data collection to determine the criteria for the incidence of tree vandalism and to establish the weighted 
Helmi Hamzah, Noriah Othman, Nur Huzeima Mohd Hussain

Setting the Criteria for Urban Tree Vandalism Assessment

criteria for a tree vandalism assessment. The questionnaire was designed to be consistent with the suggestion by Neuman (2014) that they include introductory remarks on instructions for clarification and questions to measure each variable. A Delphi draft questionnaire should be subjected to a pilot survey to check possible ambiguities that might affect the intended meaning (Bryman, 2012). Thus, the questionnaire was tested in a pilot study to ascertain its reliability before being used with a larger sample of respondents.

The Delphi survey questionnaire was designed individually for each round because different rounds served different purposes. The questionnaire in round one was to identify the relevant criteria for the incidence of tree vandalism and to ascertain the content validity of the criteria according to their categories based on expert perceptions. Meanwhile, round two of the survey was to revalidate and finalize the relevant criteria, which had yet to achieve group consensus (Brennan Ramirez et al., 2006). The survey in round two was also to examine the level of importance of each criterion for urban tree care monitoring. For the measurement of social desirability, a four-point Likert scale was used for round one, and a five-point Likert scale was used for round two of the Delphi survey (Asún, Rdz-Navarro, \& Alvarado, 2016). The questionnaires and feedback were sent and received through email. Table 1 shows the processes for the preliminary and Delphi surveys of this study.

Table 1: Analysis Process for Preliminary and Delphi Surveys

\begin{tabular}{|c|c|c|c|c|}
\hline \multirow{2}{*}{ Items } & \multirow{2}{*}{$\begin{array}{c}\text { Preliminary } \\
\text { Survey }\end{array}$} & \multicolumn{2}{|c|}{ Delphi Survey } & \multirow{2}{*}{ Results } \\
\hline & & Round 1 & Round 2 & \\
\hline Database & Photo elicitation & $\begin{array}{l}\text { - Literature } \\
\text { review } \\
\text { - Results of } \\
\text { preliminary } \\
\text { survey }\end{array}$ & $\begin{array}{l}\text { Results from } \\
\text { round } 1\end{array}$ & \multirow{5}{*}{$\begin{array}{l}\text { Comprehensive } \\
\text { criteria of the } \\
\text { incidence of tree } \\
\text { vandalism } \\
\text { (Final). }\end{array}$} \\
\hline $\begin{array}{l}\text { Number of } \\
\text { experts } \\
\text { Selected }\end{array}$ & 92 & 60 & 30 & \\
\hline $\begin{array}{l}\text { Number of } \\
\text { experts that } \\
\text { Responded } \\
\end{array}$ & 37 & 30 & 18 & \\
\hline Data analysis & Coding analysis & $\begin{array}{l}\text { Mean analysis \& } \\
\text { Amendment }\end{array}$ & Mean analysis & \\
\hline Findings & $\begin{array}{l}\text { Tree vandalism } \\
\text { categories }\end{array}$ & $\begin{array}{l}\text { Tree vandalism } \\
\text { criteria }\end{array}$ & $\begin{array}{l}\text { Revised \& } \\
\text { Finalized }\end{array}$ & \\
\hline
\end{tabular}

\section{RESULTS AND DISCUSSION}

\section{Demography of Respondents}

Out of the 92 questionnaires that were distributed to the experts, only 37 were completed in the preliminary survey. The sample comprised 27 male and 10 
female respondents. Their ages varied between 25 to 60 years, with the majority of them being from 45 to 60 years old. The respondents were predominantly Malays (26), followed by Chinese (7) and Indians (4). Almost 30 of the respondents had more than 5 years of experience as Certified Arborists, and about half of them (19) were involved as private tree care practitioners, while the rest were government servants. This indicated that the respondents in this study possessed in-depth knowledge of the topics. Table 2 presents the characteristics of the experts in the preliminary survey.

Table 2: Characteristic of Expert Respondents in Preliminary Survey

\begin{tabular}{|c|c|c|c|c|c|c|c|c|}
\hline \multirow[b]{2}{*}{ Sector } & \multirow[b]{2}{*}{$\mathbf{N}$} & \multicolumn{2}{|c|}{ Gender } & \multicolumn{3}{|c|}{ Race/Ethnic } & \multicolumn{2}{|c|}{$\begin{array}{l}\text { Experience } \\
\text { (Arborist) }\end{array}$} \\
\hline & & $\frac{0}{\tilde{J}}$ & 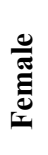 & $\frac{\vec{E}}{\sqrt{\pi}}$ & 若 & 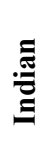 & 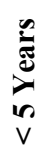 & 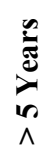 \\
\hline 1. Academic & 4 & 3 & 1 & 4 & 0 & 0 & 1 & 3 \\
\hline 2. Researcher & 4 & 4 & 0 & 3 & 0 & 1 & 0 & 4 \\
\hline 3. Local Authority & 9 & 7 & 2 & 7 & 0 & 2 & 1 & 8 \\
\hline 4. Consultant & 17 & 12 & 5 & 9 & 7 & 1 & 4 & 13 \\
\hline 5. Contractor & 2 & 1 & 1 & 2 & 0 & 0 & 1 & 1 \\
\hline $\begin{array}{l}\text { 6. Federal } \\
\text { Government }\end{array}$ & 1 & 0 & 1 & 1 & 0 & 0 & 0 & 1 \\
\hline Total & 37 & 27 & 10 & 26 & 7 & 4 & 7 & 30 \\
\hline
\end{tabular}

Meanwhile, in round one of the Delphi survey, a total of 30 responses were received, thereby giving a response rate of $63.8 \%$. Of the total number of respondents, $10.0 \%$ (3) were researchers, $13.3 \%$ (4) were academics, $20.0 \%(6)$ were from local authorities, $43.3 \%$ (13) were consultants, $6.7 \%$ (2) were contractors, and the remaining $6.7 \%$ (2) were from the federal government. In terms of their experience, 14 or $46.7 \%$ of them had been involved in the field of urban tree management for more than 20 years, another 5 experts $(16.7 \%)$ had between 15 to 20 years of experience, while the rest had between 5 to 14 years of experience. This implied that the majority of the experts had wide experience in their fields. Table 3 describes the background and experience of the experts who participated in round one of the Delphi survey.

Table 3: Profile of Expert Participants in Delphi Survey

\begin{tabular}{lccccc}
\hline Sector & >20yrs & 15-20yrs & 5-14yrs & Total & $\%$ \\
\hline 1. Researcher & 1 & 1 & 1 & 3 & 10.0 \\
2. Academic & 1 & 0 & 3 & 4 & 13.3
\end{tabular}


Helmi Hamzah, Noriah Othman, Nur Huzeima Mohd Hussain

Setting the Criteria for Urban Tree Vandalism Assessment

\begin{tabular}{lccccc} 
3. Local Authority & 4 & 0 & 2 & 6 & 20.0 \\
4. Consultant & 7 & 4 & 2 & 13 & 43.3 \\
5. Contractor & 0 & 0 & 2 & 2 & 6.7 \\
6. Federal Government & 1 & 0 & 1 & 2 & 6.7 \\
\hline \multicolumn{1}{c}{ Total } & $\mathbf{1 4}$ & $\mathbf{5}$ & $\mathbf{1 1}$ & $\mathbf{3 0}$ & $\mathbf{1 0 0}$ \\
\hline \multicolumn{10}{c}{} & $\mathbf{4 6 . 7}$ & $\mathbf{1 6 . 7}$ & $\mathbf{3 6 . 6}$ & $\mathbf{1 0 0}$ & \\
\hline
\end{tabular}

Round two of the survey received a total of 18 responses (Table 4). Of the total number of respondents in round two, $11.1 \%$ (2) were researchers, $11.1 \%$ (2) were academics, $22.2 \%$ (4) were experts from local authorities, $44.5 \%$ (8) were consultants and $11.1 \%$ (2) were contractors. Unfortunately, there was no respondent from the federal government.

Table 4: Expert Participants in Round Two of the Delphi Survey

\begin{tabular}{lcc}
\hline Sector & Experts & $\mathbf{\%}$ \\
\hline 1. Researcher & 2 & 11.1 \\
2. Academic & 2 & 11.1 \\
3. Local Authority & 4 & 22.2 \\
4. Consultant & 8 & 44.5 \\
5. Contractor & 2 & 11.1 \\
6. Federal Government & 0 & 0.0 \\
\hline \multicolumn{1}{c}{ Total } & $\mathbf{1 8}$ & $\mathbf{1 0 0}$ \\
\hline
\end{tabular}

\section{Preliminary Survey}

A descriptive analysis was executed in a systematic manner through the process of coding, sorting and synthesizing the respective meanings of the criteria for the incidence of tree vandalism. The following three categories, as stated in the theory of planned behaviour (Ajzen, 1985), were focused on: (a) the attitude of those who commit tree vandalism, (b) the perception of social pressure or subjective norms in tree vandalism behaviours, and (c) the ability to perform tree vandalism. In the first cycle of the coding process, 63 coding aspects that had been noted by the experts were sorted and synthesized by merging the repeated codes or codes that represented the same meaning. These were summarized to only 22 coding aspects and synthesized to the respective three categories; 5 codes in the Attitude category, 8 codes in the Subjective Norms category, and 9 codes in the Ability category. The coding process for identifying the criteria for the incidence of tree vandalism is reported below in Table 5 . 
PLANNING MALAYSIA

Journal of the Malaysia Institute of Planners (2020)

Table 5: Coding Process for Identifying the Criteria for the Incidence of Tree

\begin{tabular}{|c|c|c|c|}
\hline \multicolumn{4}{|c|}{ Vandalism } \\
\hline First Cycle Coding & $\begin{array}{c}\text { No. of } \\
\text { Respondents }\end{array}$ & Sorting & $\begin{array}{c}\text { Categorizing \& } \\
\text { Synthesizing }\end{array}$ \\
\hline Attitude & & & \multirow{13}{*}{$\begin{array}{l}\text { Specific Motive } \\
\text { \& Action }\end{array}$} \\
\hline 1. No Attitude. & 7 & & \\
\hline 2. Awareness. & 7 & 1. Lack of Awareness & \\
\hline 3. Curving. & 1 & 1. Lack or Awareness & \\
\hline 4. Irresponsible. & 11 & & \\
\hline 5. Beauty. & 4 & 2. Preferences \& & \\
\hline 6. Painting. & 6 & Acceptance & \\
\hline 7. Safety. & 2 & 3. Safety \& Security & \\
\hline 8. Convenience. & 1 & Priority & \\
\hline 9. Kill the Tree. & 27 & 4. Tree Hates & \\
\hline 10. Unhappy. & 1 & \multirow{3}{*}{ 5. Uncomfortable } & \\
\hline 11. Not Comfortable & 1 & & \\
\hline 12. Privacy & 1 & & \\
\hline Subjective Norm & & \multirow{3}{*}{ 1. Collaboration Failure } & \multirow{20}{*}{$\begin{array}{l}\text { Ideology \& } \\
\text { Practices }\end{array}$} \\
\hline $\begin{array}{l}\text { 13. Collaboration } \\
\text { Failure. }\end{array}$ & 2 & & \\
\hline 14. Poor Collaboration. & 1 & & \\
\hline 15. Canopy Removal. & 1 & 2. Common Practices & \\
\hline 16. Design Failure. & 6 & 3. Design Failure & \\
\hline 17. No Enforcement. & 1 & \multirow{2}{*}{ 4. Enforcement Failure } & \\
\hline 18. Enforcement Failure. & 4 & & \\
\hline 19. Ignore the Tree. & 6 & \multirow{2}{*}{ 5. Ignore the Tree } & \\
\hline 20. Don't Like Tree. & 34 & & \\
\hline 21. Management Failure. & 5 & \multirow{3}{*}{ 6. Management Failure } & \\
\hline 22. No Tree Protection. & 1 & & \\
\hline 23. No Monitoring & 1 & & \\
\hline 24. Maintenance Failure. & 13 & \multirow{8}{*}{ 7. Practices Failure } & \\
\hline 25. Practices Failure & 3 & & \\
\hline 26. Topping. & 3 & & \\
\hline 27. Usual Practices. & 1 & & \\
\hline 28. Wrong Approaches & 4 & & \\
\hline 29. Wrong Practices. & 16 & & \\
\hline 30. Bad Practices. & 14 & & \\
\hline 31. Careless. & 4 & & \\
\hline
\end{tabular}


Helmi Hamzah, Noriah Othman, Nur Huzeima Mohd Hussain

Setting the Criteria for Urban Tree Vandalism Assessment

\begin{tabular}{|c|c|c|c|}
\hline First Cycle Coding & $\begin{array}{c}\text { No. of } \\
\text { Respondents } \\
\end{array}$ & Sorting & $\begin{array}{c}\text { Categorizing \& } \\
\text { Synthesizing } \\
\end{array}$ \\
\hline $\begin{array}{l}\text { 32. Wrong Pruning } \\
\text { Method. }\end{array}$ & 1 & & \\
\hline 33. Poor Practices. & 2 & & \\
\hline 34. Religious Purposes. & 13 & 8 Religiours Purnoses & \\
\hline 35. Patriotic. & 2 & 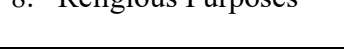 & \\
\hline Ability & & & \multirow{26}{*}{$\begin{array}{l}\text { Victim of } \\
\text { Circumstances }\end{array}$} \\
\hline $\begin{array}{l}\text { 36. Conflict with Others } \\
\text { Activities. }\end{array}$ & 6 & & \\
\hline $\begin{array}{l}\text { 37. Burning \& Dumping } \\
\text { Rubbish. }\end{array}$ & 12 & $\begin{array}{l}\text { 1. Conflict with Other } \\
\text { Activities }\end{array}$ & \\
\hline 38. Other Purposes. & 12 & & \\
\hline 39. Improper Usage. & 6 & & \\
\hline 40. Construction Work. & 16 & \multirow{8}{*}{ 2. Construction Work } & \\
\hline 41. Construct Structure. & 11 & & \\
\hline $\begin{array}{l}\text { 42. Conflict with } \\
\text { Infrastructure. }\end{array}$ & 4 & & \\
\hline 43. Machinery. & 5 & & \\
\hline 44. Construct Materials. & 8 & & \\
\hline 45. Earthwork. & 16 & & \\
\hline 46. Grade Change. & 14 & & \\
\hline $\begin{array}{l}\text { 47. Root Zone } \\
\text { Disturbance. }\end{array}$ & 10 & & \\
\hline 48. Illegal Activities. & 11 & 3. Illegal Activities & \\
\hline 49. Incidentally. & 1 & \multirow{3}{*}{ 4. Lack of Knowledge } & \\
\hline 50. No Knowledge. & 31 & & \\
\hline 51. Not Aware. & 4 & & \\
\hline 52. Obstruction. & 22 & \multirow{2}{*}{ 5. Obstruction } & \\
\hline 53. Disturbance. & 1 & & \\
\hline 54. Opportunities. & 8 & 6. Opportunities & \\
\hline $\begin{array}{l}\text { 55. Priority of Space } \\
\text { Usage. }\end{array}$ & 1 & \multirow{2}{*}{$\begin{array}{l}\text { 7. Priority of Space } \\
\text { Usage }\end{array}$} & \\
\hline 56. Space Conflict. & 4 & & \\
\hline 57. Electrical Fixtures. & 9 & \multirow{4}{*}{ 8. Structure Attachment } & \\
\hline 58. Signage Attachment. & 13 & & \\
\hline $\begin{array}{l}\text { 59. Structure } \\
\text { Attachment. }\end{array}$ & 21 & & \\
\hline 60. Nailing. & 8 & & \\
\hline
\end{tabular}


PLANNING MALAYSIA

Journal of the Malaysia Institute of Planners (2020)

\begin{tabular}{lc|c|c}
\hline First Cycle Coding & $\begin{array}{c}\text { No. of } \\
\text { Respondents }\end{array}$ & Sorting & $\begin{array}{c}\text { Categorizing \& } \\
\text { Synthesizing }\end{array}$ \\
\hline 61. Structure & 2 & & \\
$\quad$ Attachment. & 6 & 9. Supporting Element & \\
62. Supporting Element. & 11 & & \\
63. Tying. & & & \\
\hline
\end{tabular}

The codes were then categorized according to their overall meaning. The attitudes of the vandals for a specific motive and action influenced their intention to vandalise trees. Therefore, the tree vandalism criteria stemmed from the attitudes of the vandals that had been categorized according to specific motives and actions. Meanwhile, for the subjective norms, the ideologies and practices of the vandals influenced their performance of tree vandalism. Thus, the tree vandalism criteria stemmed from the subjective norms or social pressures that had been categorized as ideologies and practices. Finally, the tree vandalism incidents also occurred in a victim-of-circumstances situation. Therefore, the tree vandalism criteria also stemmed from the abilities that had been categorized as a victim of circumstances.

The criteria for the tree vandalism categories derived from the preliminary survey were then mapped with the previous research to align with the three factors that influence the incidence of urban tree vandalism, namely, the criteria of tree conditions, humans and the environment. These generated the initial criteria, which were finalized through the two rounds of the Delphi survey (Table 6), thereby yielding 21 initial criteria in three categories for the incidence of tree vandalism.

Table 6: Mapping the Criteria for Tree Vandalism Categories with the Previous

\begin{tabular}{l|l|l}
\multicolumn{2}{c}{} & \multicolumn{2}{c}{ Research } \\
\hline $\begin{array}{l}\text { Categories in } \\
\text { Tree } \\
\text { Vandalism }\end{array}$ & $\begin{array}{l}\text { Criteria for Tree } \\
\text { Vandalism Incidents }\end{array}$ & Sources (Author, Year and Country) \\
\hline \multirow{4}{*}{$\begin{array}{l}\text { 1. Specific } \\
\text { Motive and } \\
\text { Action }\end{array}$} & 1. Species of the Tree & $\begin{array}{l}\text { Camacho Cervantes, Schondube, Castillo, \& } \\
\text { MacGregor-Fors (2014); Mexico }\end{array}$ \\
\cline { 2 - 3 } & 2. Age of tree. & $\begin{array}{l}\text { Richardson \& Shackleton (2014); Eastern } \\
\text { Cape, South Africa }\end{array}$ \\
\cline { 2 - 3 } & 3. Size of the tree. & $\begin{array}{l}\text { Fernandes, Da Silva, Teixeira, \& Costa } \\
(2018) ; \text { Portugal }\end{array}$ \\
\cline { 2 - 3 } & 4. Location of the tree. & Moore (2013); Melbourne, Australia \\
\cline { 2 - 3 } & 5. The owner of the tree. & $\begin{array}{l}\text { Raskin (2015); California, United States of } \\
\text { America }\end{array}$ \\
\cline { 2 - 3 } & &
\end{tabular}


Helmi Hamzah, Noriah Othman, Nur Huzeima Mohd Hussain

Setting the Criteria for Urban Tree Vandalism Assessment

\begin{tabular}{|c|c|c|}
\hline $\begin{array}{l}\text { Categories in } \\
\text { Tree } \\
\text { Vandalism }\end{array}$ & $\begin{array}{l}\text { Criteria for Tree } \\
\text { Vandalism Incidents }\end{array}$ & Sources (Author, Year and Country) \\
\hline \multirow{10}{*}{$\begin{array}{l}\text { 2. Ideology and } \\
\text { Practices }\end{array}$} & 6. Tree characteristic. & Camacho Cervantes et al. (2014); Mexico \\
\hline & 7. Tree health condition. & $\begin{array}{l}\text { Kirkpatrick, Davison, \& Daniels (2012); } \\
\text { Australia }\end{array}$ \\
\hline & 8. Tree growth rates. & Camacho Cervantes et al. (2014); Mexico \\
\hline & $\begin{array}{l}\text { 1. Religious and cultural } \\
\text { beliefs. }\end{array}$ & Sharma \& Pegu (2011), India \\
\hline & 2. Level of knowledge. & $\begin{array}{l}\text { Richardson \& Shackleton (2014); Eastern } \\
\text { Cape, South Africa }\end{array}$ \\
\hline & 3. Socio-economic status. & $\begin{array}{l}\text { Nowak et al. (1990); California, United } \\
\text { States of America }\end{array}$ \\
\hline & 4. Rule and regulations. & $\begin{array}{l}\text { Roos (1992); Washington, United States of } \\
\text { America }\end{array}$ \\
\hline & 5. Design and layout. & Kirkpatrick et al. (2012); Australia \\
\hline & $\begin{array}{l}\text { 6. Tree maintenance } \\
\text { approaches. }\end{array}$ & Moore (2013); Melbourne, Australia \\
\hline & $\begin{array}{l}\text { 7. Tree maintenance } \\
\text { status. }\end{array}$ & Hernández Zaragoza et al. (2015); Mexico \\
\hline \multirow{6}{*}{$\begin{array}{l}\text { 3. Victim of } \\
\text { Circumstanc } \\
\text { es }\end{array}$} & $\begin{array}{l}\text { 1. Tree for structure } \\
\text { attachment. }\end{array}$ & $\begin{array}{l}\text { Travelia \& Arifin (2018); Tangerang, } \\
\text { Indonesia }\end{array}$ \\
\hline & $\begin{array}{l}\text { 2. Trees cause } \\
\text { interference/obstruction. }\end{array}$ & Gwedla \& Shackleton (2015); South Africa \\
\hline & $\begin{array}{l}\text { 3. Conflict with other } \\
\text { activities. }\end{array}$ & Kirkpatrick et al. (2012); Australia \\
\hline & 4. Priority of space usage. & Bhati \& Pearce (2016); Singapore \\
\hline & $\begin{array}{l}\text { 5. Use of tree parts for } \\
\text { other purposes. }\end{array}$ & $\begin{array}{l}\text { Richardson \& Shackleton (2014); Eastern } \\
\text { Cape, South Africa }\end{array}$ \\
\hline & $\begin{array}{l}\text { 6. Tree without a protective } \\
\text { structure. }\end{array}$ & $\begin{array}{l}\text { Richardson \& Shackleton (2014); Eastern } \\
\text { Cape, South Africa }\end{array}$ \\
\hline
\end{tabular}

\section{Round One of Delphi Survey: Identifying the Relevant Criteria}

A list of 21 criteria from three categories was included in round one of the Delphi survey. Upon completion of this round, a descriptive analysis was conducted to identify the criteria that the group of experts considered as being relevant for the incidence of tree vandalism. Table 7 shows the results for all the 21 criteria in the three tree vandalism categories (specific motives and actions, ideologies and practices, and victim of circumstances) and their respective mean scores. The group mean scores for relevance ranged from the lowest, 2.30 (age of tree: specific motives and actions category, and socio-economic status: ideologies and 
practices category) to the highest, 3.67 (tree for structural attachment and conflict with other activities: victim of circumstances). Based on the group mean agreement of relevance ( $\geq 2.01$ group mean value), the results indicated that all the 21 criteria examined in this survey achieved consensus among the experts, and, thus, were selected as relevant criteria for the incidence of tree vandalism.

Table 7: Results of Round One of Delphi Survey

\begin{tabular}{lc}
\hline Item (N=21) & Mean \\
\hline Specific motive and action category (8 criteria) & \\
1. Species of the tree. & 2.47 \\
2. Age of the tree. & 2.30 \\
3. Size of the tree. & 2.57 \\
4. $\quad$ Location of the tree. & 3.57 \\
5. The owner of the tree. & 2.90 \\
6. Tree characteristic. & 2.67 \\
7. Tree health condition. & 2.83 \\
8. Tree growth rates. & 2.63 \\
\hline Ideology and practices category (7 criteria) & \\
9. $\quad$ Religious and cultural beliefs. & 3.00 \\
10. Level of knowledge. & 3.37 \\
11. Socio-economic status. & 2.30 \\
12. Rule and regulations. & 3.37 \\
13. Design and layout. & 3.13 \\
14. Tree maintenance approaches. & 3.00 \\
15. Tree maintenance status. & 3.07 \\
\hline Victim of circumstances category (6 criteria) & \\
16. Tree for structure attachment. & 3.67 \\
17. Trees cause interference/obstruction. & 3.63 \\
18. Conflict with other activities. & 3.67 \\
19. Priority of space usage. & 3.60 \\
20. Use of tree parts for other purposes. & 2.90 \\
21. Tree without a protective structure. & 2.97 \\
\hline Note: 0 - 1 = Strongly disagree, 1.01 - 2.0 = Disagree, 2.01 - 3.0 = Agree, $3.01-4.0=$ Strongly \\
agree & \\
\hline
\end{tabular}

The experts were encouraged to modify or delete any criteria that they believed were duplicates of other criteria, and also to suggest new criteria that they believed were important but had not been included in the list so as to increase the richness of the data. Out of the 30 respondents, 16 experts took the opportunity to suggest some new criteria. There were no suggestions for the existing criteria to be modified or deleted; however, the experts took the opportunity to suggest 11 new relevant criteria which they believed were important to consider but were not included in the existing list of criteria. Table 
Helmi Hamzah, Noriah Othman, Nur Huzeima Mohd Hussain

Setting the Criteria for Urban Tree Vandalism Assessment

8 shows a shortlist of these new criteria derived from a pool of suggestions from these experts. There were an additional two criteria for the specific motives and actions category, four criteria for the ideologies and practices category, while five new criteria were added to the victim of circumstances category.

Table 8: Additional New Criteria Suggested by Experts

\begin{tabular}{l|l}
\hline New criteria & Category \\
\hline 1. $\quad$ Tree debris. & Specific motive and action \\
\hline 3. $\quad$ Tree value. & \\
4. Deordination and cooperation. & Ideology and practices \\
5. Tree care monitoring. & \\
6. Information on Tree Benefits. & \\
\hline 7. Infrastructure upgrading/extension \& & \\
8. $\quad$ Event and occasion. & Victim of circumstances \\
9. $\quad$ Rate of the human population. & \\
10. $\quad$ Memorial display. & \\
11. $\quad$ Tree as a protective structure. & \\
\hline
\end{tabular}

\section{Round Two of Delphi Survey: Identifying the Important Criteria}

Following the identification of the relevant criteria in round one, round two was conducted to confirm these relevant criteria and examine their level of importance for a tree vandalism assessment. A list of 32 criteria was sent out to all the 30 experts who had completed the previous round of the Delphi survey. The results indicated that the group mean value of importance ranged from the lowest: 1.83 (socio-economic status: ideologies and practices category) to the highest, 3.78 (conflict with other activities and infrastructure upgrading/extension \& urbanization/development both in the victim of circumstances category). All the 32 criteria from all three categories achieved consensus ( $\geq 1.01$ group mean value) (Table 9).

The analysis to determine the level of importance of each criterion was conducted based on the ranking order of the mean values (Gosavi, 2015), as shown in Table 9. The results indicated that the 'location of the tree' was the most important criterion (ranking no. 1), and the 'age of the tree' was the least important (ranking no. 10) for the specific motives and actions category. The 'level of knowledge' was the most important criterion (ranking no. 1), while the 'socioeconomic status' was the least important (ranking no. 11) in the category of ideologies and practices. Meanwhile, the 'conflict with other activities' was the most important criterion (ranking no. 1), and the 'tree as a protective structure' was the least important (ranking no. 11) for the victim of circumstances category. 
PLANNING MALAYSIA

Journal of the Malaysia Institute of Planners (2020)

Table 9: Delphi Round Two Results

\begin{tabular}{|c|c|c|c|}
\hline Item $(\mathrm{N}=32)$ & Mean & Variance & Ranking \\
\hline \multicolumn{4}{|l|}{ Specific motive and action (10 criteria) } \\
\hline 1. Species of tree & 2.78 & 0.54 & 5 \\
\hline 2. Age of tree & 1.94 & 0.53 & 10 \\
\hline 3. Size of tree & 3.17 & 0.85 & 2 \\
\hline 4. Location of tree & 3.61 & 0.37 & 1 \\
\hline 5. The owner of the tree & 2.72 & 0.57 & 6 \\
\hline 6. Tree characteristic & 2.72 & 0.80 & 7 \\
\hline 7. Tree health condition & 3.11 & 0.58 & 3 \\
\hline 8. Tree growth rates & 3.11 & 0.81 & 4 \\
\hline 9. Tree debris & 2.61 & 0.37 & 8 \\
\hline 10. Tree value & 2.06 & 0.64 & 9 \\
\hline \multicolumn{4}{|l|}{ Ideology and practices (11 criteria) } \\
\hline 11. Religious and cultural beliefs & 2.72 & 0.80 & 8 \\
\hline 12. Level of knowledge & 3.67 & 0.24 & 1 \\
\hline 13. Socio-economic status & 1.83 & 1.44 & 11 \\
\hline 14. Rule and regulations & 3.67 & 0.35 & 2 \\
\hline 15. Design and layout & 3.11 & 0.58 & 4 \\
\hline 16. Tree maintenance approaches & 3.06 & 1.00 & 6 \\
\hline 17. Tree maintenance status & 2.94 & 0.64 & 7 \\
\hline 18. Coordination and cooperation & 2.67 & 1.41 & 9 \\
\hline 19. Demographic (age) & 2.33 & 0.82 & 10 \\
\hline 20. Tree care monitoring & 3.06 & 0.88 & 5 \\
\hline 21. Information on tree benefits & 3.22 & 0.65 & 3 \\
\hline \multicolumn{4}{|l|}{ Victim of circumstances (11 criteria) } \\
\hline 22. Tree for structure attachment & 3.67 & 0.35 & 5 \\
\hline 23. Trees cause interference/obstruction & 3.67 & 0.24 & 4 \\
\hline 24. Conflict with other activities & 3.78 & 0.18 & 1 \\
\hline 25. Priority of space usage & 3.72 & 0.21 & 3 \\
\hline 26. Use of tree parts for other purposes & 2.67 & 0.71 & 8 \\
\hline 27. Tree without protective structure & 3.06 & 0.64 & 6 \\
\hline $\begin{array}{l}\text { 28. Infrastructure upgrading/extension \& } \\
\text { urbanization/development }\end{array}$ & 3.78 & 0.18 & 2 \\
\hline 29. Event and occasion & 3.00 & 0.71 & 7 \\
\hline 30. Rate of the human population & 2.39 & 0.72 & 9 \\
\hline 31. Memorial display & 2.39 & 0.84 & 10 \\
\hline 32. Tree as a protective structure & 2.39 & 0.96 & 11 \\
\hline
\end{tabular}

Note: Mean $0-1.0=$ Not important, $1.01-2.0=$ Least important, $2.01-3.0=$ Average important, $3.01-4.0=$ Absolutely important. 
Helmi Hamzah, Noriah Othman, Nur Huzeima Mohd Hussain

Setting the Criteria for Urban Tree Vandalism Assessment

\section{CONCLUSION}

The research generated 32 important criteria for use in assessing the incidence of tree vandalism for urban tree care monitoring. The set of criteria determined in this study provides the necessary guidance to identify the incidence of tree vandalism in urban areas. More importantly, it provides accurate data for policymakers and tree managers to make effective decisions concerning tree vandalism issues.

This research has shown that the photographic method known as the photoelicitation technique is able to provide richness to the qualitative data required from experts for an initial investigation into tree vandalism. This research has also demonstrated the value of the Delphi survey as a potential tool for generating important tree vandalism criteria, and in helping to generate the criteria ranking. Undoubtedly, since the criteria for a tree vandalism assessment have been determined in this research, further studies are needed to develop the indicators to represent the status of tree vandalism.

\section{ACKNOWLEDGEMENT}

The authors would like to express their appreciation to the respondents for their willingness to participate in and to give their time for this survey, and without whom, this study could not have been carried out. We gratefully acknowledge the contribution of Universiti Teknologi MARA in providing the Bestari Perdana Research Grant for this research (600-IRMI/PERDANA 5/3 BESTARI $(056 / 2018)$.

\section{REFERENCES}

Abd Kadir, M. A., \& Othman, N. (2012). Towards a better tomorrow: Street trees and their values in urban areas. Procedia - Social and Behavioral Sciences, 35, $267-$ 274. https://doi.org/10.1016/j.sbspro.2012.02.088

Ajzen, I. (1985). From intentions to actions: A theory of planned behavior. In Kuhl \& Beckmann (Eds.), Action control: From cognition to behavior (pp. 11-39). New York, Unites Stated of America: Springer-Verlag. https://doi.org/10.1007/978-3642-69746-3_2

Alvarez Etxeberria, I., Garayar, A., \& Calvo Sánchez, J. A. (2015). Development of sustainability reports for farming operations in the Basque country using the Delphi method. Spanish Accounting Review, 18(1), 44-54. https://doi.org/10.1016/j.rcsar.2014.03.004

Asún, R. A., Rdz-Navarro, K., \& Alvarado, J. M. (2016). Developing multidimensional Likert scales using item factor analysis: The case of four-point items. Sociological Methods and Research, 45(1), 109-133. https://doi.org/10.1177/0049124114566716

Bhati, A., \& Pearce, P. (2016). Vandalism and tourism settings: An integrative review. Tourism Management, 57,91-105. https://doi.org/10.1016/j.tourman.2016.05.005 
Bogner, A., Littig, B., \& Menz, W. (2009). Expert interviews: An introduction to a new methodological debate. In B. Kittel (Ed.), Interviewing experts (pp. 1-13). England: Macmillan Publishers Limited. https://doi.org/10.1057/9780230244276

Brennan Ramirez, L. K., Hoehner, C. M., Brownson, R. C., Cook, R., Orleans, C. T., Hollander, M., ... Wilkinson, W. (2006). Indicators of activity-friendly communities. An evidence-based consensus process. American Journal of Preventive Medicine, 31(6), 515-524. https://doi.org/10.1016/j.amepre.2006.07.026

Bryman, A. (2012). Social research methods (4th ed.). New York, Unites Stated of America: Oxford University Press Inc. Retrieved from https://www.academia.edu/30520568/Social_Research_Methods_4th_Edition_b y_Alan_Bryman.pdf

Camacho Cervantes, M., Schondube, J. E., Castillo, A., \& MacGregor-Fors, I. (2014). How do people perceive urban trees: Assessing likes and dislikes in relation to the trees of a city. Urban Ecosystems, 17, 761-773. https://doi.org/10.1007/s11252014-0343-6

Delshammar, T., Östberg, J., \& Öxell, C. (2015). Urban trees and ecosystem disservices - A pilot study using complaints records from three swedish cities. Arboriculture \& Urban Forestry, 41(4), 187-193. Retrieved from https://www.researchgate.net/publication/281993776_Urban_trees_and_ecosyste $\mathrm{m}$ _disservices_A_pilot_study_using_complaints_records_from_three_Swedish cities

Donovan, G. H., \& Prestemon, J. P. (2012). The effect of trees on crime in Portland, Oregon. Environment and Behavior, 44(1), 3-30. https://doi.org/10.1177/0013916510383238

Fernandes, C. O., Da Silva, I. M., Teixeira, C. P., \& Costa, L. (2018). Between tree lovers and tree haters. Drivers of public perception regarding street trees and its implications on the urban green infrastructure planning. Urban Forestry and Urban Greening, 1-12. https://doi.org/10.1016/j.ufug.2018.03.014

Gilbertson, P., \& Bradshaw, A. D. (1985). Tree survival in cities: The extent and nature of the problem. Arboricultural Journal: The International Journal of Urban Forestry, 9(2), 131-142. https://doi.org/10.1080/03071375.1985.9746706

Gosavi, A. (2015). Analyzing responses from Likert surveys and risk-adjusted ranking: A data analytics perspective. Procedia Computer Science, 61, 24-31. https://doi.org/10.1016/j.procs.2015.09.139

Grande-Ortiz, M. A., Ayuga-Téllez, E., \& Contato-Carol, M. L. (2012). Methods of tree appraisal: A review of their features and application possibilities. Arboriculture and Urban Forestry, 38(4), 130-140. Retrieved from https://www.researchgate.net/publication/285958344_Methods_of_tree_appraisa 1_A_review_of their_features_and application possibilities

Greco, $\overline{\text { S., }}$ Ishizaka, $\bar{A}$., Tasiou, M., \& Torrisi, G. (2019). On the methodological framework of composite indices: A review of the issues of weighting, aggregation, and robustness. Social Indicators Research, 141(1), 61-94. https://doi.org/10.1007/s11205-017-1832-9 
Helmi Hamzah, Noriah Othman, Nur Huzeima Mohd Hussain

Setting the Criteria for Urban Tree Vandalism Assessment

Gwedla, N., \& Shackleton, C. M. (2015). The development visions and attitudes towards urban forestry of officials responsible for greening in South African towns. Land Use Policy, 42, 17-26. https://doi.org/10.1016/j.landusepol.2014.07.004

Hami, A., Suhardi, M., Manohar, M., \& Malekizadeh, M. (2014). The relationship between landscape planting patterns and perceived safety in urban parks in Tabriz, Iran. African Journal of Environmental Science and Technology, 8(2), 107-113. https://doi.org/10.5897/AJEST2013.1486

Hamzah, H., Othman, N., \& Mohd Hussain, N. H. (2017). Tree removal application by urban dwellers: A case study of Kajang local authority. In C. Dewi \& E. N. Rauzi (Eds.), International Conference on Architecture 2017 (ICRP-AVAN), Unsyiah (Banda Aceh) and UiTM (Perak) (pp. 1-5). Banda Aceh, Indonesia: Jurusan Arsitektur Fakultas Teknik Universitas Syiah Kuala. Retrieved from http://icrpavan.unsyiah.ac.id/open/Cover\&Contents.pdf

Hamzah, H., Othman, N., Mohd Hussain, N. H., \& Simis, M. (2018). The criteria of urban trees regarding the issues of tree vandalism. IOP Conference Series: Earth and Environmental Science, 203, 1-6. https://doi.org/10.1088/17551315/203/1/012023

Hasan, R., Othman, N., \& Ismail, F. (2018). Social factors influencing hazardous street trees at selected city council in Malaysia. Asian Journal of Quality of Life, 2(5), 77-85. https://doi.org/10.21834/ajqol.v3i12.144

Hasson, F., Keeney, S., \& McKenna, H. (2000). Research guidelines for the Delphi survey technique. Journal of Advanced Nursing, 32(4), 1008-1015. https://doi.org/10.1046/j.1365-2648.2000.t01-1-01567.x

Henning, J. I. F., \& Jordaan, H. (2016). Determinants of financial sustainability for farm credit applications: A Delphi study. Multidisciplinary Digital Publishing Institute, 8(77), 1-15. https://doi.org/10.3390/su8010077

Hernández Zaragoza, A. Y., Cetina Alcalá, V. M., López, M. Á., Hilú, A. C., De La Isla De Bauer, M. D. L., Rosales, D. A., \& Rosas, H. G. (2015). Identification of tree damages of three parks of Mexico City. Mexican Journal of Forest Sciences, 6(32), 63-82. Retrieved from https://pdfs.semanticscholar.org/b593/36ec05b743e3efa45226a302f9c068c6e0ab .pdf

Jeste, D. V., Ardelt, M., Blazer, D., Kraemer, H. C., Vaillant, G., \& Meeks, T. W. (2010). Expert consensus on characteristics of wisdom: A delphi method study. The Gerontologist, 50(5), 668-680. https://doi.org/10.1093/geront/gnq022

Kirkpatrick, Davison, A., \& Daniels, G. D. (2012). Resident attitudes towards trees influence the planting and removal of different types of trees in eastern Australian cities. Landscape and Urban Planning, 107(2), 147-158. https://doi.org/10.1016/j.landurbplan.2012.05.015

Long, M., \& Burke, R. H. (2015). Vandalism and anti-social behaviour. (P. Davies, P. Francis, \& T. Wyatt, Eds.), Critical Criminological Perspectives. Australia: Palgrave Macmillan. https://doi.org/10.1057/9781137519269

Lyytimäki, J. (2017). Disservices of urban trees. In F. Francesco, C. C. Van Den Bosch, \& F. Alessio (Eds.), Routledge Handbook of Urban Forestry (pp. 164-176). London: Routledge. https://doi.org/10.4324/9781315627106 
Mayring, P. (2000). Qualitative content analysis. Forum: Qualitative Social Research, 1(2), 1-10. https://doi.org/10.1111/j.1365-2648.2007.04569.x

Mohd Yunos, M. Y., \& Md Saring, Z. (2012). Perceptions of urban residential landcsapes: Role of plants in enhancing outdoor thermal comfort. Alam Cipta, 5(2), 119-128. Retrieved from http://frsb.upm.edu.my/alamcipta/index.php/alamcipta/article/view/70

Moore, G. M. (2013). Ring-barking and girdling: How much vascular connection do you need between roots and crown. In N. Wojcik (Ed.), The 14th National Street Tree Symposium (pp. 87-96). Adelaide, Australia: University of Melbourne. Retrieved from https://pdfs.semanticscholar.org/21d8/3db275574be4aedb9805071741eddf1afb6 a.pdf?_ga=2.146494001.481915270.1570351625-2133761217.1557440011

Mullaney, J., Lucke, T., \& Trueman, S. J. (2015). A review of benefits and challenges in growing street trees in paved urban environments. Landscape and Urban Planning, 134, 157-166. https://doi.org/10.1016/j.landurbplan.2014.10.013

Nardo, M., Saisana, M., Saltelli, A., \& Tarantola, S. (2005). Tools for composite indicators building. OECD-JRC Handbook of composite indicators building (Vol. EUR 21682). Italy. Retrieved from http://farmweb.jrc.cec.eu.int/ci/bibliography.htm EUR

Neuman, W. L. (2014). Social research methods: Qualitative and quantitative approaches (7th ed.). United States of America: Pearson Education Limited. Retrieved from https://www.pdfdrive.com/social-research-methods-qualitative-and-quantitativeapproaches-e19744746.html

Nowak, McBride, J. R., \& Beatty, R. A. (1990). Newly planted street tree growth and mortality. Journal of Arboriculture, 16(5), 124-129. Retrieved from http://nrs.fs.fed.us/pubs/jrnl/1990/ne_1990_nowak_001.pdf

Osakabe, Y., Kawaoka, A., Nishikubo, $\bar{N}$., \& Osakabe, K. (2012). Responses to environmental stresses in woody plants: Key to survive and longevity. Journal of Plant Research, 125, 1-10. https://doi.org/10.1007/s10265-011-0446-6

Raskin, E. (2015). The definitive guide to tree disputes in California. Hastings Environmental Law Journal, 21(1), 113-137. Retrieved from https://repository.uchastings.edu/cgi/viewcontent.cgi?article=1325\&context=hast ings_environmental_law_journal

Richardson, E., \& Shackleton, C. M. (2014). The extent and perceptions of vandalism as a cause of street tree damage in small towns in the Eastern Cape, South Africa. Urban Forestry and Urban Greening, 13, 425-432. https://doi.org/10.1016/j.ufug.2014.04.003

Roos, H. E. (1992). Vandalism as a symbolic act in free zones. In H. H. Christensen, D. R. Johnson, \& M. H. Brookes (Eds.), Vandalism: Research, prevention and social policy (pp. 71-87). Seattle: US Dept. of Agruculture / Pacific Northwest Research Station and University of Washington. Retrieved from https://lup.lub.lu.se/search/ws/files/5546900/802127.pdf

Roy, S., Byrne, J., \& Pickering, C. (2012). A systematic quantitative review of urban tree benefits, costs, and assessment methods across cities in different climatic zones. Urban Forestry and Urban Greening, 11, 351-363. https://doi.org/10.1016/j.ufug.2012.06.006 
Helmi Hamzah, Noriah Othman, Nur Huzeima Mohd Hussain

Setting the Criteria for Urban Tree Vandalism Assessment

Salazar-Elena, J. C., Sánchez, M. P., \& Otamendi, F. J. (2016). A non-parametric Delphi approach to foster innovation policy debate in Spain. Multidisciplinary Digital Publishing Institute, 8(487), 1-26. https://doi.org/10.3390/su8050487

Sekaran, U., \& Bougie, R. (2016). Research methods for business (7th ed.). United Kingdom: John Wiley \& Sons Ltd. Retrieved from https:/www.academia.edu/36294585/Research-Methods-For-Business-A-SkillBuilding-Approach-7th_edition.pdf

Sharma, U. K., \& Pegu, S. (2011). Ethnobotany of religious and supernatural beliefs of the mising tribes of Assam with special reference to the 'Dobur Uie.' Journal of Ethnobiology and Ethnomedicine, 7(16), 1-13. https://doi.org/10.1186/17464269-7-16

Sieghardt, M., Mursch Radlgruber, E., Paoletti, E., Couenberg, E., Dimitrakopoulus, A., Rego, F., ... Randrup, T. B. (2005). The abiotic urban environment: Impact of urban growing conditions on urban vegetation. In C. C. Konijnendijk, K. Nilsson, T. B. Randrup, \& J. Schipperijn (Eds.), Urban forests and trees (pp. 281-323). Netherlands: Springer Berlin Heidelberg New York. Retrieved from https://www.pdfdrive.com/urban-forests-and-trees-a-reference-booke184300005.html

Stewart, D., Gibson-Smith, K., MacLure, K., Mair, A., Alonso, A., Codina, C., ... Wiese, B. (2017). A modified Delphi study to determine the level of consensus across the European Union on the structures, processes and desired outcomes of the management of polypharmacy in older people. PLoS ONE, 12(11), 1-17. https://doi.org/10.1371/journal.pone.0188348

Travelia, I., \& Arifin, H. S. (2018). Tree management at Boulevard landscape of Alam Sutera Serpong, a new city area in Tangerang. IOP Conference Series: Earth and Environmental Science, 203(1-9). https://doi.org/10.1088/1755$1315 / 203 / 1 / 012022$

UTGL. (2015). Urban tree monitoring protocols: Field guide. Gainesville, FL: Arboriculture Research \& Eduction Academy of the International Society of Arboriculture. Retrieved from www.urbantreegrowth.org

Vogt, J. M., Watkins, S. L., Mincey, S. K., Patterson, M. S., \& Fischer, B. C. (2015). Explaining planted-tree survival and growth in urban neighborhoods: A socialecological approach to studying recently-planted trees in Indianapolis. Landscape and Urban Planning, 136, 130-143. https://doi.org/10.1016/j.landurbplan.2014.11.021 